\title{
Semicontinuous Fermentation of Cassava by Streptococcus bovis Using Membrane Bioreactor to Produce Lactic Acid
}

\author{
SURIPTO D. YUWONO ${ }^{1 *}$, WASINTON SIMANJUNTAK ${ }^{1}$, FITRIANI ${ }^{2}$, TAKAO KOKUGAN ${ }^{2}$, \\ SUTOPO HADI ${ }^{1}$ \\ ${ }^{1}$ Department of Chemistry, University of Lampung, Jl. Prof. Dr. Sumantri Brojonegoro No. 1, Bandar Lampung, Indonesia \\ ${ }^{2}$ Department of Chemical Engineering, Tokyo University of Agriculture and Technology, Tokyo 183-0057, Japan
}

Abstract: The main objective of this study is to compare the production of lactic acid from cassava by Streptococcus bovis in semicontinuous system with and without membrane separation. Fermentation was run for $72 \mathrm{~h}$, and membrane filtration was performed using micro filtration membrane (MF). The results obtained demonstrate that higher productivity of lactic acid was achieved using fermentation coupled with membrane separation. It was also found that dilution rate (D) of $0.02 \mathrm{~h}^{-1}$ led to slight increase in the lactic acid productivity. Despite this small increase, this investigation shows that membrane separation has the potential to improve the performance of semicontinuous fermentation system.

Keywords: cassava, fermentation, lactic acid, micro filtration (MF), semi continuous, S. bovis

\section{Introduction}

Lactic acid is recognized as a very valuable compound for its wide range of applications, from traditional uses such as chemical, soft drinks, medicine, and foodstuff, to more advanced materials such as biodegradable polymer and medical ingredients [1]. Both chemical route and fermentation process can be used to produce lactic acid; however the latter is more widely used for several advantageous reasons. Fermentation process requires cheaper raw materials and lower production cost since the process can be run in low temperature, thus reducing the cost for energy. In addition, fermentation is a highly specific process, enabling the production of pure L and D-lactic acid, which are the desired stereoisomers [2-6].

Lactic acid by fermentation can be produced from different types of raw material, among them are glucose, xylose, sucrose, lactose, and cassava [7-11], therefore offering the flexibility in selecting raw material considering the availability and necessary pretreatment, as well as the cost of fermentation [12]. In Indonesia, cassava is a very promising raw material for production of lactic acid, since this agriculture commodity is abundantly available in different regions, in which the Province of Lampung is one of the main producing regions $[13,14]$. The use of cassava is also supported by the existence of several species of bacteria capable to carry out the fermentation of this raw material, such as $S$. bovis $[15,16]$ and $L$. manihotivorans [17].

Productions of lactic acid through fermentation of starch by $S$. bovis have been reported in previous studies, using batch system [11] and fed batch and continuous modes [18,19]. The results of these previous studies indicate that each system has its own advantages as well as disadvantages. For batch system, the main drawback observed was decreased concentration and productivity of lactic acid, most likely due to inhibition by starch in high concentration, which is acknowledged as a main obstacle of batch culture [11]. In this respect, the variation in fermentation processes should be acknowledged bay taking into account the type and characteristics of raw materials, microbial growth, and the media of fermentation.

The present investigation was conducted as an attempt to develop an efficient fermentation process for production of lactic acid from cassava in single stage [18] and two stages [19]. The main objective of the study was to compare the performance of semicontinuous system with and without membrane separation $(\mathrm{MF})$.

*email: suripto.dwi@fmipa.unila.ac.id 


\section{Materials and methods}

\subsection{Materials}

Cassava was used as a substrate (5g/L), while Tryptosoya broth (TSB) (Nissui Pharmeutical, Tokyo) was used as the basic medium. TSB consisted of the following (per 24,2 4, liter of distilled water): 17 g peptone, $3 \mathrm{~g}$ soybean peptone, $2.5 \mathrm{~g}$ glucose, $2.5 \mathrm{~g} \mathrm{~K} \mathrm{HPO} 2.5 \mathrm{~g} \mathrm{KH} \mathrm{PO} 5 \mathrm{~g} \mathrm{NaCl}$. The basic medium and substrate solution were then sterilized by autoclaving at $121^{\circ} \mathrm{C}$ for $15 \mathrm{~min}$. The seed culture of $S$. bovis JCM 5802 used was similar to the one that has been used in our previous work [19, 20].

\subsection{Semicontinuous Fermentation}

Anaerobic fermentation experiment was conducted in $3.5 \mathrm{~L}$ chamber, at fixed temperature of $39^{\circ} \mathrm{C}$. During the experiment, the $p \mathrm{H}$ of the broth was controlled using $\mathrm{pH}$ meter ( $\mathrm{pH}$ meter type HM-50GDKK-TOA Corp., Japan), and maintained at specified value, by adding $6 \mathrm{~N} \mathrm{NH}_{4} \mathrm{OH}$ solution to neutralize the acid. The sample was agitated with the speed of $390 \mathrm{rpm}$. Membrane separation was carried out using $0.1 \mu \mathrm{m}$ thickness MF membrane. Substrate and medium were supplied into the chamber using plunger pump and fermentation broth was regulated by reciprocating pump.

A series of experiments were conducted at $p \mathrm{H}$ of 5.5 to study semicontinuous technique with membrane separation. Before commencing semicontinuous experiments, batch fermentation was carried out for $24 \mathrm{~h}$, during which time the concentration of remaining glucose was estimated to decrease to $5-10 \mathrm{~g} \mathrm{~L}^{-1}$, based on previous batch fermentations. After the completion of batch experiment, semicontinuous fermentation experiments with membrane separation was undertaken by removing an aliquot of $1440 \mathrm{~mL}$ of fermentation broth from the system and fresh media contained 30 and $50 \mathrm{~g} \mathrm{~L}^{-1}$ cassava were added every $24 \mathrm{~h}$ of interval time. Samples were taken before and after filling fresh media every $24 \mathrm{~h}$. During the continuous fermentation with membrane separation, permeate was continuously removed through membrane separation with constant flow rate of at $0.066 \mathrm{~L} \mathrm{~h}^{-1}$ by regulation valve, and fresh medium was added to the system with flow rate about $0.068 \mathrm{~L} \mathrm{~h}^{-1}$.

\subsection{Analysis}

For analysis, an aliquot of broth was drawn aseptically from the system and the concentrations of lactic acid and residual starch were determined with a biosensor (Oji Scientific Instruments, Osaka). Since the permeate side of the membrane was not sterile, the number of Streptococcus bovis cells (CFU $\left.(\mathrm{mL})^{-1}\right)$ in $0.1 \mathrm{~mL}$ diluted sample was estimated by plate count technique. This counting was conducted using bromocresol purple agar medium (Nissui Pharmaceutical, Tokyo) after incubating the sample for $72 \mathrm{~h}$ at $37^{\circ} \mathrm{C}$ in anaerobic condition.

\section{Results and discussions}

The results after $24 \mathrm{~h}$ batch experiment followed by semicontinuous treatment with membrane separation at different times and $0.02 \mathrm{~h}^{-1}$ dilution rate are shown in Figure 1. As can be seen, increased viable cell in the reactor was observed up to $72 \mathrm{~h}$ of experiment. It was also found in the experiment fed with substrate contained 50 g.L. $\mathrm{L}^{-1}$ cassava, gradual increase of lactic acid concentration took place from transition period of $24 \mathrm{~h}$ and reached 19 g.L. $\mathrm{L}^{-1}$ after $48 \mathrm{~h}$, and about $7.8 \mathrm{~g} . \mathrm{L}^{-1}$ residual starch in the filtrate. Semicontinuous culture commenced when the cassava reached lactic acid produced has almost constant concentration at $19 \mathrm{~g} \mathrm{~L}^{-1}$ until 7 days of operation. Lactic acid produced from this operating mode (semicontinuous with membrane separation) has similar concentration every day. This constant concentration differs from batch mode which has more variation in lactic acid produced. There was also an increasing of viable cell because of batch feeding of new substrate and cell was recycled back to the vessel by membrane separation. The experiment fed with substrate contained $30 \mathrm{~g} \mathrm{~L}^{-1}$ cassava was found to produce very low yield (Table 1, row 2) 


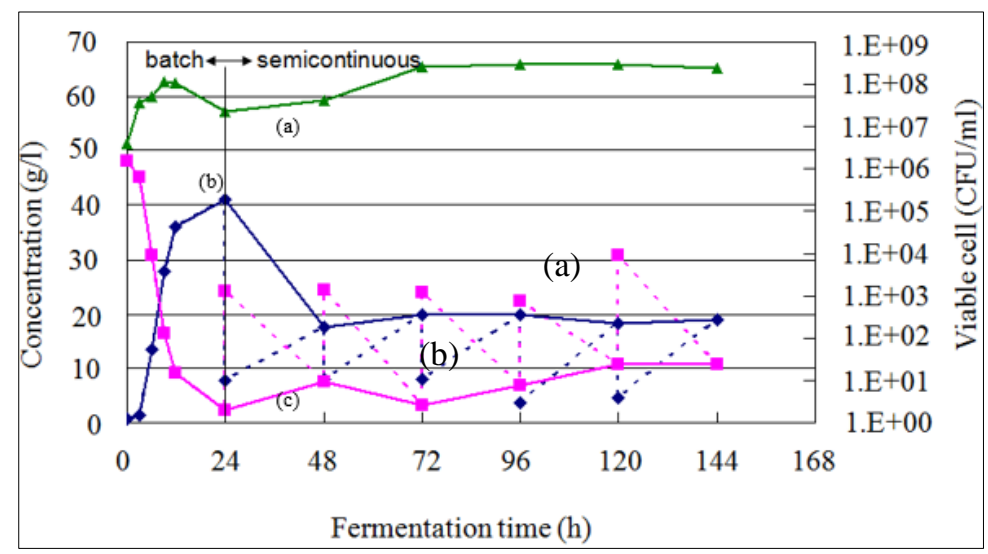

\section{Figure 1.}

Semicontinuous

fermentation with

membrane separation

$\mathrm{D}=0.02 \mathrm{~h}^{-1}$ : (a) viable

cell; (b) lactic acid

concentration;

(c) starch concentration

Typical example of the results obtained from semicontinuous experiment without membrane for experimental time of $144 \mathrm{~h}$ is presented in Figure 2. As can be seen, the concentration of lactic acid has reached the value of about $13 \mathrm{~g} . \mathrm{L}^{-1}$ after $72 \mathrm{~h}$, and the concentration of lactic acid increased up to $18 \mathrm{~g}$. $\mathrm{L}^{-1}$. As a result, the productivity achieved was $0.33 \mathrm{gL}^{-1} \cdot \mathrm{h}^{-1}$ for the third and fourth stage of fermentation, or equivalent to specific productivity of $1.2 \mathrm{~h}^{-1}$. Higher productivity than that achieved in this study was reported in previous investigation with the use of continuous processes coupled with membrane separation [19]. It is then clear that the use of MF to prevent the buildup of lactic acid in the bioreactor will increase the reaction rate of lactic acid formation, leading to higher productivity.

During the experiments, the conditions were controlled to ensure the concentration of starch was within the range of $19-20 \mathrm{~g} \mathrm{~L}^{-1}$ in bioreactor and less than $5 \mathrm{gL}^{-1}$ in the permeate effluent. This step was taken because if the concentration of starch reaches $25 \mathrm{gL}^{-1}$ in the reactor, the fermentation was hindered by inhibiting effect of the concentration, leading to suppressed formation of lactic acid. Application of recycled cells after membrane separation, to obtain high cell density, was found to result in higher concentration and yield of lactic acid produced. As can be seen in Table 1, dilution rate of $0.02 \mathrm{~h}^{-1}$ resulted in lactic acid with concentration of $19 \mathrm{gL}^{-1}$ and yield of $0.75 \mathrm{gL}^{-1}$. The concentration of lactic acid achieved in this study is relatively higher than that reported in previous study [21], in which $S$. cremoris was used for fermentation of whey permeate with the concentration of $5.38 \mathrm{~g} \mathrm{~L}^{-1}$. In another study [22], production of lactic acid from cane molasses was investigated. In the study, L. plantarum was used to determine the performance of conventional continuous culture. The results obtained demonstrated that maximum volumetric productivity achieved was closely related to low concentration of lactic acid high concentration of unreacted molasses total sugars [22].

Figure 3 displays the results of experiment carried out with starch concentration of $50 \mathrm{gL}^{-1}$ and dilution rate of $0.02 \mathrm{~h}^{-1}$, resulting in $0.39 \mathrm{gL}^{-1} \mathrm{~h}^{-1}$ as the maximum productivity for lactic acid. For batch system, concentration, productivity, and yield of lactic acid are $42 \mathrm{gL}^{-1}, 0.84 \mathrm{gL}^{-1} \mathrm{~h}^{-1}$, and $3.44 \mathrm{gL}^{-1}$, respectively (Table 1). In Table 1, the initial cassava concentration [ $\mathrm{C}_{\text {So }}$ ], dilution rate (D), lactic acid concentration $\left[\mathrm{C}_{\mathrm{LA}}\right]$ and residual starch concentration $\left[\mathrm{R}_{\mathrm{S}}\right]$ were directly measured as described in analysis section, while the calculation of the productivity $\left(\mathrm{P}_{\mathrm{LA}}\right)$, specific growth rate $(\mu)$ and yield of lactic acid $\left(\mathrm{Y}_{\mathrm{P} / \mathrm{S}}\right)$ the following formula as in Equations 1 to 3 were used.

$$
\begin{aligned}
& \left(\mathrm{P}_{\mathrm{LA}}\right)=\left[\mathrm{C}_{\mathrm{LA}}\right] \times \mathrm{D} \\
& \left(\mu=\ln \left(\mathrm{X}_{2} / \mathrm{X}_{1}\right) /\left(\mathrm{t}_{2}-\mathrm{t}_{1}\right)\right.
\end{aligned}
$$

where $\mathrm{X}_{2}=$ cell concentration at time $\mathrm{t}_{2}$

$$
\begin{aligned}
& \mathrm{X}_{1}=\text { cell concentration at time } \mathrm{t}_{1} \\
& \mathrm{Y}_{\mathrm{P} / \mathrm{S}}=\left[\mathrm{C}_{\mathrm{LA}}\right] /\left[\mathrm{C}_{\mathrm{S} 0}\right] \times 100 \%
\end{aligned}
$$

As seen in Table 1, both concentration and yield of lactic acid obtained from continuous system are analogous to those obtained using semicontinuous fermentation, but continuous fermentation resulted in much higher productivity compared to that of semicontinuous fermentation. 


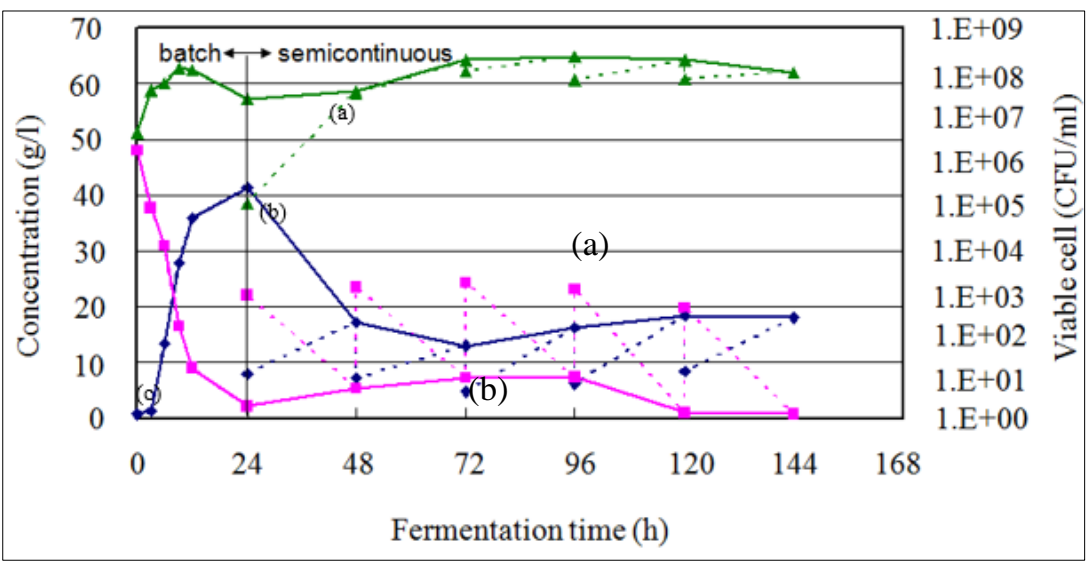

\section{Figure 2.}

Semicontinuous fermentation without membrane separation, $\mathrm{D}=0.02 \mathrm{~h}^{-1}:$ (a) viable cell; (b) lactic acid concentration; (c) starch concentration

Table 1. Kinetic parameters of each fermentation mode

\begin{tabular}{|c||c|c|c|c|c|c|c|c|c|}
\hline No & Operating mode & $\begin{array}{c}\text { Time } \\
{[\mathrm{days}]}\end{array}$ & $\begin{array}{c}\mathrm{Cs} \\
{\left[\mathrm{g} \mathrm{L}^{-1}\right]}\end{array}$ & $\begin{array}{c}\mathrm{D} \\
{\left[\mathrm{h}^{-1}\right]}\end{array}$ & $\begin{array}{c}\mathrm{CLA}_{\mathrm{LA}} \\
{\left[\mathrm{g} \mathrm{L}^{-1}\right]}\end{array}$ & $\begin{array}{c}\mathrm{Rs} \\
{\left[\mathrm{g} \mathrm{L}^{-1}\right]}\end{array}$ & $\begin{array}{c}\mathrm{PLA}_{\mathrm{LA}} \\
{\left[\mathrm{g} \mathrm{L}^{-1} \mathrm{~h}^{-1}\right]}\end{array}$ & $\begin{array}{c}\mu \\
{\left[\mathrm{h}^{-1}\right]}\end{array}$ & $\begin{array}{c}\mathrm{YP} / \mathrm{S} \\
{[-]}\end{array}$ \\
\hline 1 & Batch & 3 & 50 & - & 42 & 5 & 3.44 & 0.85 & 0.84 \\
\hline 3 & $\begin{array}{c}\text { Semicontinuous with } \\
\text { membrane }\end{array}$ & 7 & 30 & 0.01 & 16.5 & 4.4 & 0.16 & - & 0.22 \\
\hline 4 & $\begin{array}{c}\text { Semicontinuous with } \\
\text { membrane }\end{array}$ & 7 & 50 & 0.02 & 19 & 7.8 & 0.38 & - & 0.75 \\
\hline 5 & $\begin{array}{c}\text { Semicontinuous } \\
\text { without membrane }\end{array}$ & 7 & 50 & 0.02 & 13 & 4.4 & 0.33 & - & 0.52 \\
\hline
\end{tabular}

Note: $\left[\mathrm{Css}_{\mathrm{So}}\right]=$ initial cassava concentration, $\mathrm{D}=$ dilution rate, $\left[\mathrm{C}_{\mathrm{LA}}\right]=$ lactic acid concentration,

$[\mathrm{Rs}]=$ residual starch concentration, $\mathrm{PLA}_{\mathrm{LA}}=$ productivity, $\mu=$ specific growth rate,

$\mathrm{Y}_{\mathrm{P} / \mathrm{S}}=$ Yield of Lactic acid

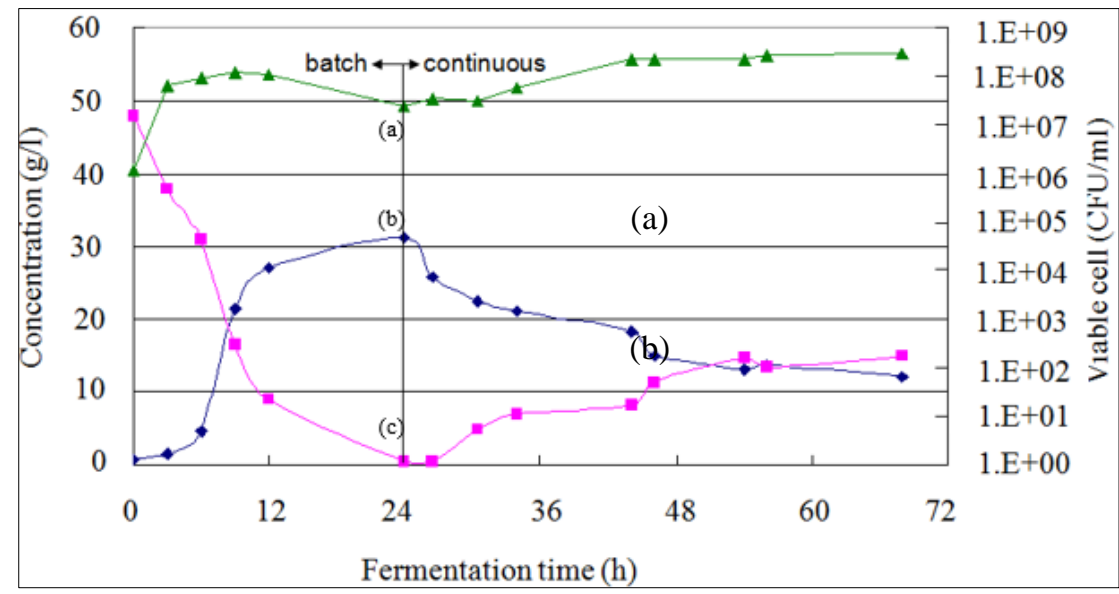

Figure 3. Continuous fermentation with membrane separation:

(a) viable cell;

(b) lactic acid concentration;

(c) starch concentration

The results obtained from semicontinuous system with and without membrane, at different rates of dilution are compiled in Table 1. As can be seen, the same D of $0.02 \mathrm{~h}^{-1}$ was observed for both systems, but higher concentration of lactic acid in the filtrate (19 g.. $\left.{ }^{-1}\right)$ was produced by the system with membrane. These results demonstrated that the high performance of membrane last for long period of time, thus supporting high activity of cells in the fermenter to conduct fermentation. Kinetic parameters for semicontinuous fermentation with and without membrane, and dilution rates are included in Table 1. To achieve better fermentation results, the inhibitory effect of lactic concentration should be 
suppressed, which can be done by running the system at low dilution rate and using comparatively lower viable cell [11].

As observed in previous study [15], lactic acid concentration of $50 \mathrm{~g} \mathrm{~L}^{-1}$ caused severe damage of $S$. bovis. This finding is in agreement with the result of the present study, which revealed that suppression of lactic acid to less than $50 \mathrm{gL}^{-1}$ during the fermentation process is required order to maintain high viability of the cell. Concentration of lactic acid produced using S. bovis is appreciably lower than that achieved using L. amylovorus. In investigation by others [23], it was reported that lactic acid production directly from cassava with initial liquefied starch concentration of $120 \mathrm{~g} \mathrm{~L}^{-1} \mathrm{using}$ L. amylovorus in a batch fermenter resulted in lactic acid concentration of $96.2 \mathrm{~g}$ after $20 \mathrm{~h}$. The study also revealed that lactate with concentration of $92.5 \mathrm{gL}^{-1}$ was produced from raw starch of the same concentration in $39 \mathrm{~h}$. Conversion of starch might proceed either through primary hydrolysis of starch molecule or direct conversion of starchy substrate to lactic acid by amylolytic organisms [24]. In direct conversion of starch, it was acknowledged that different results were obtained from different substrates. As examples, utilization of corn starch produced lactic acid with concentration $0.68 \mathrm{gL}^{-1}$ [25], and production of lactic acid from liquefied starch using L. plantarum NCIM 2084 was reported to produce lactic acid with concentration of $0.729 \mathrm{gL}^{-1}[26]$.

\section{Conclusions}

In conclusion, this study showed a maximum lactic acid productivity of $0.38 \mathrm{gL}^{-1} \mathrm{~h}^{-1}$, where the optimal lactic acid production conditions were starch feed concentration of $50 \mathrm{gL}^{-1}$ and $0.02 \mathrm{~h}^{-1}$ dilution rate. Furthermore, since the semicontinuous process was shown to produce a similar amount of lactic acid to the continuous culture experiment.

Acknowledgments: The authors would like to thank to the Directorate of Research and Community Service, Directorate General of Higher Education, The Ministry of Research, and Technology and National Research and National Agency, Republic of Indonesia that provide fund for this project to be undertaken through Penelitian Dasar 2020.

\section{References}

1. BAlABAn, M., VIRGOliCI, B., DINU, A., TOTAN, A., MIRICESCU, D., STEFAN, D., GREABU, M., MOHORA, M., Metabolic Parameters in Wistar Rats Treated with Glucocorticosteroids and Vitamin E-Charged Poly Lactic-Co-Glycolic Acid (PLGA) Nanoparticles, Rev. Chim., 70(4), 2019, 1315-1318.

2. JIN, B., YIN, P., MA, Y., ZHAO, L. Production of Lactic Acid and Fungal Biomass by Rhizopus Fungi from Food Processing Waste Streams, J. Ind. Microbiol. Biot., 32(11-12), 2005, 678-686.

3. JOHN, R.P., NAMPOOTHIRI, K.M., PANDEY, A., Fermentative Production of Lactic Acid from Biomass: An Overview of Process Developments and Future Perspectives, Appl. Microbiol. Biot., 74(3), 2007, 524-534.

4. RAO, C.S., PRAKASHAM, R.S., RAO, A.B., YADAV, J.S., Production of L (+) Lactic Acid by Lactobacillus delbrueckii Immobilized in Functionalized Alginate Matrices, World J. Microbiol. Biot., 24(8), 2008, 1411-1415.

5. ARUS, V.A., JINESCU, C., NISTOR, I.D., ISOPENCU, G., Ultrasound Intensification of Lactic Fermentation Process in the Presence of Anionic Clays, Rev. Chim., 65(8), 2014, 942-947

6. ARUS, V.A., NISTOR, I.D., PLATON, N., ROSU, A.M., MUNTIANU, G., JINESCU, C., Statistical Modelling and Optimization of Lactic Acid Fermentation in the Presence of Anionic Clay and Ultrasonic Field, Rev. Chim., 66(1), 2015, 88-91

7. GUO, Y., YAN, Q., JIANG, Z., TENG, C., WANG, X., Efficient Production of Lactic Acid from Sucrose and Corncob Hydrolysate by a Newly Isolated Rhizopus oryzae GY18, J. Ind. Microbiol. Biot., 37, 2010, 1137-1143. 
8. PAGANA, I., MORAWICKI, R., HAGER, T.J., Lactic Acid Production Using Waste Generated from Wet Potato Processing, Int. J. Food Sci.Tech., 49(2), 2014, 641-649.

9. SAITO, K., HASA, Y., ABE, H., Production of Lactic Acid from Xylose and Wheat Straw by Rhizopus oryzae, J. Biosci.Bioeng., 114(2), 2012, 166-169.

10. TAY, A., YANG, S.T., Production of L (+) - Lactic Acid from Glucose and Starch by Immobilized Cells of Rhizopus Oryzae in a Rotating Fibrous Bed Bioreactor, J. Biotech. Bioeng., 80(1), 2002, 1-12

11. YUWONO, S.D., GHOFAR, A., KOKUGAN, T., Effect of Product Inhibition on L-Lactic Acid Fermentation from Fresh Cassava Roots in Tofu Liquid Waste by Streptococcus bovis, Jpn. J. Food Eng., 9(1), 2008, 59-66.

12. YEN, H.W., KANG J.L., Lactic Acid Production Directly from Starch in a Starch Controlled Fed Batch Operation Using Lactobacillus amylophilus. Bioproc. Biosyst. Eng., 33(9), 2010, 1017-1023.

13. Arief, R.W., UTOMO, J.S., ASNAWI, R., Development processing of cassava into cassava flour and modified cassava flour in Lampung Province, Buletin Palawija, 24, 2012, 82-91.

14.WIDIARTO, S., YUWONO, S.D., ROCHLIADI, A., ARCANA, I.M., Preparation and Characterization of Cellulose and Nanocellulose from Agro-industrial Waste - Cassava Peel, IOP Conf. Ser.: Mater. Sci. Eng., 176, 2017, 012052

15. GHOFAR, A., OGAWA, S., KOKUGAN, T., Production of L-Lactic Acid from Fresh Cassava Roots Slurried with Tofu Liquid Waste by Streptococcus bovis, J. Biosci. Bioeng., 100(6), 2008. 606612.

16. NARITA, J., NAJAHARA, S., FUKUDA, H., KONDO, A., Efficient Production of L(+)-Lactic Acid from Raw Starch by Streptococcuds bovis 148. J. Biosci. Bioeng., 97(6), 2004, 423-425.

17. SON, M.-S., KWON, Y.-J., Direct Fermentation of Starch to L-Lactic acid by Fed-Batch Culture of Lactobacillus manihotivorans, Food Sci. Biotechnol., 22(1), 2013, 289-293.

18. YUWONO, S.D., HADI, S., FITRIANI, KOKUGAN, T., Lactic acid Production from Fresh Cassava Rooots Using Single Stage Membrane Bioreactor, Modern Appl. Sci., 6(1), 2012, 60-67.

19. YUWONO, S.D., MULYONO, WIDIARTO, S., HADI, S., AND KOKUGAN, T., Improvement of Lactic Acid Production from Cassava by Streptococcus bovis Using Two-Stages Membrane Bioreactor, Asian J. Chem., 26(18), 2014, 6249-6252.

20. YUWONO, S.D., HADI, S., Production of Lactic Acid from Onggok and Tofu Liquid Waste with Concentrate Maguro Waste Supplement by Streptococcus bovis, Aus. J. Basic Appl. Sci., 2(4), 2008, 939-942.

21. MULLIGAN, C.M., SAFI, B.F., GROLEAU, D., Continuous Production of Ammonium Lactate by Streptococcus cremoris in a Three-Stage Reactor, Biotechnol. Bioeng., 38(10), 1991, 1173-1181.

22. GOMEZ, V.R., GARCIA, J.L., Lactic Acid Productivity in Continuous Culture of Cane Molasses with Lactobacillus plantarum, In Proceedings of the First Lactic Acid Bacteria Computer Conference (Eds. FOO, E. L., GRIFFIN, R., MOELBY R., HEDEN, C.G., Horizon Scientist-DC Press), 1993, $107-$ 110.

23. ZHANG, D.X., CHERYAN, M., Direct Fermentation of Starch to Lactic Acid by Lactobacillus amylovorus, Biotechnol. Lett., 13, 1991, 733-738.

24. OHKOUCH, Y., AND INOUE, Y., Direct Production of L(+)-Lactic Acid from Starch and Food Wastes Using Lactobacillus manihotivorans LMG 18011, Bioresource Technol., 97(13), 2006, 15541562.

25. MERCIER, P., YERUSHALMI, L., ROULEAU, D., DOCHAIN, D., Kinetics of Lactic Acid Fermentation on Lucose and Corn by Lactobacillus amylophilus, J. Chem. Technol. Biot., 55(2), (1992). 111-121.

26. KRISHNAN, S., BHATTACHARYA, S., KARANTH, N.G., Media Optimization for Production of Lactic Acid by Lactobacillus plantarum NCIM 2084 Using Response Surface Methodology, Food Biotechnol., 12(1-2), 1998, 105-110

Manuscript received: 30.03 .2020 